\title{
BIOACTIVE DITERPENES AND SESQUITERPENES FROM THE RHIZOMES OF WILD GINGER (SIPHONOCHILUS AETHIOPICUS (SCHWEINF) B.L BURTT)
}

\author{
Ngozichukwuka Peace Igoli. ${ }^{a^{*}}, Z^{2}$ ak Ahamefula Obanu ${ }^{b}$, Alexander I. Gray ${ }^{c}$, Carol Clements $^{c}$ \\ ${ }^{\mathrm{a} D e p a r t m e n t ~ o f ~ S c i e n c e, ~ C o l l e g e ~ o f ~ A d v a n c e d ~ a n d ~ P r o f e s s i o n a l ~ S t u d i e s ~ M a k u r d i, ~ N i g e r i a ~}$ \\ ${ }^{\mathbf{b}}$ Department of Food Science and Technology, University of Nigeria, Nsukka, Nigeria \\ 'Natural Product Laboratories, SIPBS, University of Strathclyde, 27 Taylor Street, Glasgow, G4 ONR \\ *E-mail: ngozi_igoli@yahoo.com
}

\begin{abstract}
Wild ginger (Siphonochilus aethiopicus (Schweinf) B.L Burtt) is used in traditional medicines in the West and South of Africa. In the present study, the crude hexane extract of wild ginger was evaluated for in vitro bioactivity. The components isolated from the plant for the first time are: epi-curzerenone, furanodienone (sesquiterpenes), 8(17),12E-labdadiene-15,16-dial, 15-hydroxy-8(17),12E-labdadiene-16-al and 16-oxo-8(17),12E-labdadiene-15-oic acid (labdanes). Cytotoxicity determinations using five cell lines: SH-SY5Y (human, Caucasian, bone marrow, neuroblastoma), Jurkat (human, peripheral blood, leukaemia T cell), L929 (mouse, CH3/connective tissue, areolar and adipose tumour cells), Hep G2 (human, Caucasian, hepatocellular carcinoma) and Hs 27 (normal, human, foreskin cells) were carried out. Anti-trypanosomal activity against Trypanosoma brucei brucei (S427) blood stream forms and anti-bacterial activity against Mycobacterium aurum (CIP .104482) were also investigated. Activity against $M$. aurum was moderate and at $100 \mu \mathrm{g} / \mathrm{ml}$, the crude extract together with the labdanes showed specific cytotoxicity, indicating anti-cancer potency. Anti-trypanosomal activity was observed in the crude extract which increased with the pure components: $8(17), 12 \mathrm{E}-$ labdadiene-15,16-dial $(\mathrm{MIC}=5.3 \mu \mathrm{M})$ and the sesquiterpenoids $(\mathrm{MIC}=6.9 \mu \mathrm{M})$ as compared to suramin activity $(\mathrm{MIC}=10 \mu \mathrm{M})$. This anti-trypanosomal activity which is being reported for the first time indicates possible usage against sleeping sickness and nagana in cattle.
\end{abstract}

Key words: Anti-bacterial activity; Anti-trypanosomal activity; Cytotoxicity; Labdane diterpenoids; Sesquiterpenoids; Siphonochilus aethiopicus.

\section{Introduction}

Wild ginger (Siphonochilus aethiopicus (Schweinf) B.L Burtt) is an annual plant of the Zingiberaceae family growing in Nigeria which has purple flowers with white corolla tubes. Between September to December, the shoot withers and falls off. The flowers start shooting out of the ground between April to May after the early rains and appear before the leaves. The tubers or rhizomes are spindle shaped and arranged radially on lateral roots (Burkill, 2000). The South African varieties have white to bright pink flowers with yellow markings on lip and appear between October to February (Kiew, 1980; Holzapfel et al., 2002). The rhizomes of both varieties are used medicinally for colds, coughs, influenza, hysteria, infections, wound dressing, fevers and pain amongst other ailments. The Igede people of Benue State in Nigeria also use the rhizome as a spice.

Before the advent of industrially prepared medicines, herbal remedies were commonly prescribed and were often effective. Thus herbs and spices played important, sometimes magical, roles in medicine. In the middle of 2006, the botanical preparation Hemoxin/Nicosan was approved in Nigeria following demonstration of efficacy in clinical trials as a treatment for sickle cell anemia. This mixture of four plants that came from native healer information can be classified as a "true ethnobotanical preparation" (Newman and Cragg, 2007). Analysis of the sources of new and approved drugs for the treatment of human diseases indicated that natural products continued to play a highly significant role in the drug discovery and development process. Thus biologically active natural products from plants, their derivatives or analogues contributed up to $57 \%$ of top selling prescription drugs in the United States in 1997 (Newman et al., 1997). This dominant role is due to the fact that natural products serve as a lead for the design and synthesis of clinically useful agents. Thus expanding, not decreasing, the exploration of nature as a source of novel active agents that may serve as the leads and scaffolds for elaboration into desperately needed efficacious drugs for a multitude of disease indications is advocated (Newman and Cragg, 2007).

Many of the Zingiberaceae plants are used as spices and in traditional medicine (Firman et al., 1988; Kirk, 1991; Igoli et al., 2005). The ethnobotanical use of wild ginger against a wide variety of ailments prompted our investigation of the fresh rhizomes of this plant with a view to isolating the compounds responsible for its medicinal value. We observed that the crude hexane extracts of the fresh plant material showed selective cytotoxicity, significant anti-trypanosomal activity against the African trypanosome blood forms of Trypanosoma brucei brucei (S427) and anti-bacterial activity against Mycobacterium aurum (CIP .104482). It therefore became desirable to isolate the constituents responsible for this bioactivity. 
Two eudesmane sesquiterpenoids: 4a $\alpha \mathrm{H}-3,5 \alpha, 8 \mathrm{a} \beta$-Trimethyl-4,4a,8a,9-tetrahydronaphtho[2,3b]-furan-8-one and 2-hydroxy$4 \mathrm{a} \alpha \mathrm{H}-3,5 \alpha, 8 \mathrm{a} \beta$-trimethyl-4,4a,8a,9-tetrahydro-naphtho[2,3b]- furan- $8(5 \mathrm{H})$-one were isolated as the major constituents of the South African variety (Holzapfel et al., 2002). Efforts to isolate and characterize the constituents of these crude extracts have led to the isolation of the elemane sesquiterpenoid, epi-curzerenone (1), the germacrane sesquiterpenoid, furanodienone $(8,12$-epoxy1(10),4,7,11-germacratetraen-6-one) (2) and the labdane diterpenoids: 8(17),12E-labdadiene-15,16-dial (3), 15-Hydroxy8(17),12E-labdadiene-16-al (4), and 16-Oxo-8(17), 12E-labdadiene-15-oic acid ( Zerumin A) (5). We hereby report on the in vitro activity of the crude extracts and these compounds isolated from the plant for the first time against the test organisms.

\section{Materials and methods Plant material}

Fresh rhizomes of wild ginger (Siphonochilus aethiopicus (Schweinf) B.L Burtt) were harvested from the university farmlands of the University of Agriculture, Makurdi, Benue State, Nigeria in September 2007. The plant was authenticated by the Department of Forestry and Wildlife of the University where a voucher specimen No 172 was deposited in the University of Agriculture Forest Herbarium.

\section{Extraction and isolation of the components}

The fresh ground rhizomes $(1.00 \mathrm{~kg})$ were macerated with GC-grade hexane. The solvent was allowed to dry off in a fume cupboard at room temperature to obtain $5.92 \mathrm{~g}$ of the crude extract. Column chromatographic separation of the crude extract was performed on $2.00-3.00 \mathrm{~cm}$ internal diameter glass columns using silica gel MN-60 (Macherey-Nagel GmbH \& Co. KG). The column was prepared by pouring slurry of $100 \mathrm{~g}$ of silica gel in hexane into the glass column then subsequently a dry mixture of the crude extract and silica gel. Elution was gradient- wise with GC-grade hexane -ethyl acetate solvents. The crude extract and column fractions were examined by spots on TLC (Silica gel $60 \mathrm{GF}_{254}$; Merck) under UV 254 and 365nm before visualisation using Anisaldehyde- $\mathrm{H}_{2} \mathrm{SO}_{4}$ chromogenic reagent and heating. Column fractions were collected until no more compounds were isolated.

\section{NMR and HRGC-MS analyses}

The ${ }^{1} \mathrm{H}$ and ${ }^{13} \mathrm{C}$ NMR (400 MHz) spectra were run in a JEOL spectrometer using $\mathrm{CDCl}_{3}$ as solvent and TMS as internal standard. DEPT and two dimensional NMR measurements like the ${ }^{1} \mathrm{H}-{ }^{1} \mathrm{H}$ correlation COSY and ${ }^{1} \mathrm{H}^{13} \mathrm{C}$ correlations: HMQC and HMBC on JEOL ( $400 \mathrm{MHz})$ NMR were also used to elucidate the structures of all the compounds isolated. LTQ Orbitrap Thermo at a capillary temperature of $200^{\circ} \mathrm{C}$ and capillary voltage of $46.00 \mathrm{~V}$ for the positive polarity and $-48.00 \mathrm{~V}$ for the negative polarity was used for ESI HRMS.

\section{Cytotoxicity determinations}

This Alamar blue redox-based assay was carried out according to the method of O'Brien et al., (2000) for the cell lines: SH-SY5Y (human, Caucasian, bone marrow, neuroblastoma), Jurkat (human, peripheral blood, leukaemia T cell), L929 (mouse, $\mathrm{CH} 3$ /connective tissue, areolar and adipose tumour cells), Hep G2 (human, Caucasian, hepatocellular carcinoma) and Hs 27 (normal, human, foreskin cells). Three replicates were made. $130 \mu \mathrm{l}$ of cells were seeded at appropriate concentrations (SH-SY5Y at $10^{4}$; Jurkat at $3 \times 10^{4}$; L929 at $10^{4}$; Hep G2 at $3 \times 10^{4}$ and Hs 27 at $10^{4}$ cells/well) in DMEM. Fluorescence was determined on a Wallac Victor microplate reader in fluorescence mode (Excitation 530nm; Emission 590nm)

\section{Anti-trypanosomal activity}

A modification of the microplate Alamar blue assay to determine drug sensitivity of African trypanosomes in vitro according to (Raz et al., 1997) was used. Stock solutions of plant extracts/ isolates were prepared as $10 \mathrm{mg} / \mathrm{ml}$ in DMSO and serially diluted in HMI-9 medium, the negative control. $10 \mu \mathrm{M}$ suramin was the positive control. Trypanosomes blood forms used were Trypanosoma brucei brucei S427 and the concentrations of trypanosomes were $2-3 \times 10^{4}$ trypanosomes $/ \mathrm{ml}$. Incubation was at $37^{\circ} \mathrm{C}, 5 \% \mathrm{CO}_{2}$ with a humidified atmosphere for 48 hours for three replicates made. Alamar blue was used and fluorescence determined on a Wallac Victor microplate reader in fluorescence mode (Excitation 530nm; Emission 590nm).

\section{Anti-bacterial activity}

A modification of the microplate Alamar blue method for susceptibility testing of fast growing species of Mycobacterium (Collins and Franzblau, 1997 and Franzblau et al., 1998) was used. Mycobacterium aurum CIP.104482 was subcultured onto Columbia agar slopes ( $5 \%$ horse blood), incubated at $37^{\circ}$ and prepared for MIC determination. $1000 \mu \mathrm{g} / \mathrm{ml}$ solution of the test compounds in DMSO was serially diluted in MHB (Mueller Hinton broth), the negative control. $6 \mu \mathrm{g} / \mathrm{ml}$ ethambutol controls and Alamar blue were used for three replicates made. Fluorescence was determined on a Wallac Victor microplate reader in fluorescence mode (Excitation 530nm; Emission 590nm). 


\section{Results}

The step-wise gradient elution of the hexane extract with hexane, and hexane-ethyl acetate mixtures yielded five compounds (Figure 1) according to their polarity: (1; 44.3mg) first, followed by (2; 107.5mg) isolated by 5\% EtOAc, (3; 127.5mg) 10\% EtOAc, (4; 74.0mg):15\% EtOAc and (5; 10.0mg): $30 \%$ EtOAc.

The in vitro activity of the crude extracts and the isolated compounds against the cell lines and the test organisms are shown in Tables 1 and 2 respectively. These compounds were screened for cytotoxicity against five different cell lines. The two sesquiterpenoids ( $1 \& 2$ ) were inactive against the five different cell lines tested. Two of the diterpenes 8(17),12E-labdadiene15,16-dial (3) and 15-hydroxy-8(17),12E-labdadiene-16-al (4) however, had specific cytotoxic effects. 8(17),12E-Labdadiene15,16-dial had moderate effect on the normal cell line (Hs 27) and was cytotoxic to SH-SY5Y, Jurkat and L929. However only Jurkat and SH-SY5Y were affected by 15-hydroxy-8(17),12E-labdadiene-16-al.

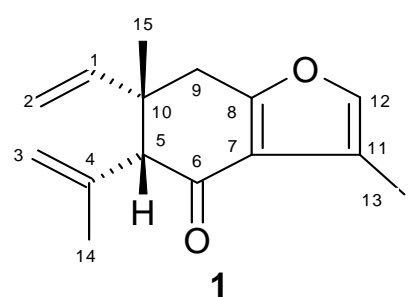

1

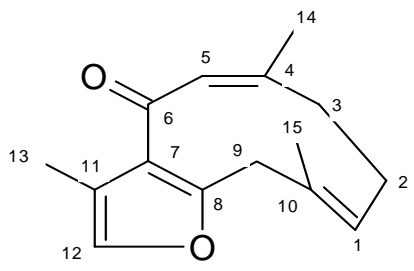

2

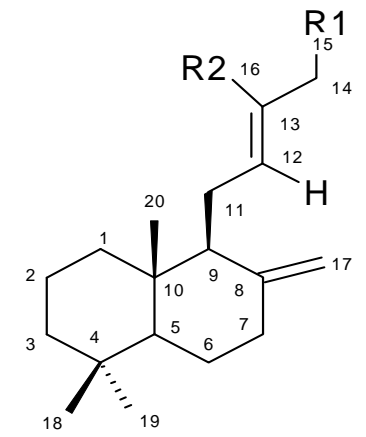

3: $\mathrm{R} 1=\mathrm{R} 2=\mathrm{CHO}$

4: $\mathrm{R} 1=\mathrm{OH}, \mathrm{R} 2=\mathrm{CHO}$

5: $\mathrm{R} 1=\mathrm{COOH}, \mathrm{R} 2=\mathrm{CHO}$

Figure 1: The structures of isolated compounds from the rhizome of S. aethiopicus .

1: Epi-curzerenone

2: Furanodienone

3: 8(17),12E-labdadiene-15,16-dial

4: 15-Hydroxy-8(17),12E-labdadiene-16-al

5: 16-Oxo-8(17), 12E-labdadiene-15-oic acid

Table 1: Cytotoxicity tests

\begin{tabular}{|c|c|c|c|c|c|}
\hline & \multicolumn{4}{|c|}{ Cell lines } & \\
\hline & & & ontrol $\mathrm{f}$ & $0 \mu \mathrm{g} / \mathrm{m}$ & \\
\hline & Hep G2 & Hs 27 & Jurkat & L929 & SH-SY5Y \\
\hline \multicolumn{6}{|l|}{ Extract/compd } \\
\hline Crude extract & 107 & 114.2 & 54.1 & 104.5 & 53.3 \\
\hline 1 & 103 & 102.8 & 62.0 & 101.1 & 82.4 \\
\hline 2 & 101 & 105.5 & 70.4 & 102.3 & 90.3 \\
\hline 3 & 107 & 68.8 & 4.1 & 47.4 & 9.0 \\
\hline 4 & 116 & 107.4 & 55.1 & 107.3 & 35.9 \\
\hline 5 & - & - & - & - & - \\
\hline
\end{tabular}

Table 2: MIC of Bioactivity tests $(\mu \mathrm{g} / \mathrm{ml})$

\begin{tabular}{lccc}
\hline Extract/compound & \multicolumn{3}{c}{ Test organism } \\
\hline \multirow{2}{*}{ Crude extract } & & M.aurum & T. brucei \\
& $\mathbf{1}$ & 250 & 6.25 \\
& $\mathbf{2}$ & - & $1.55(6.9 \mu \mathrm{M})$ \\
& $\mathbf{3}$ & - & $1.55(6.9 \mu \mathrm{M})$ \\
& $\mathbf{4}$ & 250 & $1.55(5.3 \mu \mathrm{M})$ \\
& $\mathbf{5}$ & 125 & $6.25(20.7 \mu \mathrm{M})$ \\
Suramin & & - & $50(157.2 \mu \mathrm{M})$ \\
Ethambutol & & 6 & $10(\mu \mathrm{M})$ \\
\hline
\end{tabular}




\section{Discussion}

The ${ }^{1} \mathrm{H}$ and ${ }^{13} \mathrm{C}$ NMR spectral data for the compounds were in agreement with already published data (Hikino et al., 1975; Brieskorn and Noble, 1982; Lorimer and Weavers, 1987; Itokawa et al., 1988; Xu et al., 1996; Sy and Brown, 1997 and Zhou et al., 1997) as shown in Tables 3 and 4 respectively. The exact masses of the molecular ions of the compounds 3, 4, \& 5 (ESI HRMS) $\mathrm{m} / \mathrm{z}$ were $302.2319,304.2475$ and 318.2122 respectively corresponding to the molecular formulae: $\mathrm{C}_{20} \mathrm{H}_{30} \mathrm{O}_{2} ; \mathrm{C}_{20} \mathrm{H}_{32} \mathrm{O}_{2}$ and $\mathrm{C}_{20} \mathrm{H}_{30} \mathrm{O}_{3}$.

Table 3: ${ }^{1} \mathrm{H}$ and ${ }^{13} \mathrm{C}$ NMR Spectral Data of 1 and 2 (Sesquiterpenes) in $\mathrm{CDCl}_{3}(400 \mathrm{MHz}$ )

\begin{tabular}{|c|c|c|c|c|c|}
\hline $\begin{array}{l}H- \\
\text { Position }\end{array}$ & Epi-curzerenone & Furanodienone & C-Position & Epi-curzerenone & Furanodienone \\
\hline $1-\mathrm{H}$ & $5.79 \mathrm{dd} \mathrm{J}=10.6,17.2 \mathrm{~Hz}$ & $5.16 \mathrm{~m}$ & $\mathrm{C}-1$ & $145.6(\mathrm{CH})$ & $130.6(\mathrm{CH})$ \\
\hline $2-\mathrm{H}$ & $4.94 \mathrm{~d} \mathrm{~J}=17.2 \mathrm{~Hz}$ & $2.16 \mathrm{~m}$ & $\mathrm{C}-2$ & $113.0\left(\mathrm{CH}_{2}\right)$ & $25.5\left(\mathrm{CH}_{2}\right)$ \\
\hline $2-\mathrm{H}$ & $4.94 \mathrm{~d} \mathrm{~J}=10.6 \mathrm{~Hz}$ & $2.26 \mathrm{~m}$ & $\mathrm{C}-3$ & $115.7\left(\mathrm{CH}_{2}\right)$ & $40.7\left(\mathrm{CH}_{2}\right)$ \\
\hline $3-\mathrm{H}$ & $4.74 \mathrm{~s}$ & $1.86 \mathrm{dt} \mathrm{J}=4.4 \mathrm{~Hz}$ & C-4 & $141.1(\mathrm{C})$ & $145.9(\mathrm{C})$ \\
\hline $3-\mathrm{H}$ & $4.99 \mathrm{~m}$ & $2.45 \mathrm{td} \mathrm{J}=3.7 \mathrm{~Hz}$ & C-5 & $64.1(\mathrm{CH})$ & $132.5(\mathrm{CH})$ \\
\hline \multirow[t]{3}{*}{$5-\mathrm{H}$} & \multirow[t]{3}{*}{$3.00 \mathrm{~s}$} & \multirow[t]{3}{*}{$5.79 \mathrm{~s}$} & C-6 & $194.5(\mathrm{C})$ & $189.9(\mathrm{C})$ \\
\hline & & & $\mathrm{C}-7$ & $119.3(\mathrm{C})$ & 124.1(C) \\
\hline & & & C-8 & $165.5(\mathrm{C})$ & $156.6(\mathrm{C})$ \\
\hline $9-\mathrm{H}$ & $2.89 \mathrm{~d} \mathrm{~J}=17.6 \mathrm{~Hz}$ & $3.69 \mathrm{~m}$ & C-9 & $33.7\left(\mathrm{CH}_{2}\right)$ & $41.8\left(\mathrm{CH}_{2}\right)$ \\
\hline 9-H & $2.77 \mathrm{~d} J=17.6 \mathrm{~Hz}$ & $3.69 \mathrm{~m}$ & $\mathrm{C}-10$ & $41.8(\mathrm{C})$ & $135.5(\mathrm{C})$ \\
\hline $12-\mathrm{H}$ & $7.06 \mathrm{~d} J=1.10 \mathrm{~Hz}$ & $7.06 \mathrm{~d} \mathrm{~J}=1.32 \mathrm{~Hz}$ & $\mathrm{C}-11$ & 119.3(C) & 122.3(C) \\
\hline 13- Me & $2.16 \mathrm{~d} J=1.10 \mathrm{~Hz}$ & $2.12 \mathrm{~d} \mathrm{~J}=1.32 \mathrm{~Hz}$ & $\mathrm{C}-12$ & $139.6(\mathrm{CH})$ & $138.2(\mathrm{CH})$ \\
\hline 14-Me & $1.81 \mathrm{~s}$ & $1.98 \mathrm{~s}$ & C-13 & $9.0\left(\mathrm{CH}_{3}\right)$ & $9.6\left(\mathrm{CH}_{3}\right)$ \\
\hline \multirow[t]{2}{*}{$15-\mathrm{Me}$} & $1.17 \mathrm{~s}$ & $1.28 \mathrm{~s}$ & $\mathrm{C}-14$ & $25.0\left(\mathrm{CH}_{3}\right)$ & $19.1\left(\mathrm{CH}_{3}\right)$ \\
\hline & & & $\mathrm{C}-15$ & $24.9\left(\mathrm{CH}_{3}\right)$ & $15.9\left(\mathrm{CH}_{3}\right)$ \\
\hline
\end{tabular}

Table 4: ${ }^{1} \mathrm{H}$ and ${ }^{13} \mathrm{C}$ NMR Spectral Data of 3, 4 and 5 (Labdanes) in $\mathrm{CDCl}_{3}(400 \mathrm{MHz})$

\begin{tabular}{|c|c|c|c|c|c|c|}
\hline \multirow[t]{2}{*}{ Position } & \multicolumn{2}{|c|}{ Compound 3} & \multicolumn{2}{|c|}{ Compound 4} & \multicolumn{2}{|c|}{ Compound 5} \\
\hline & ${ }^{13} \mathrm{C}_{\delta \mathrm{ppm}}$ & ${ }^{1} \mathrm{H}_{\delta \mathrm{ppm}}$ & ${ }^{13} \mathrm{C}_{\delta \mathrm{ppm}}$ & ${ }^{1} \mathrm{H}_{\delta \mathrm{ppm}}$ & ${ }^{13} \mathrm{C}_{\delta \mathrm{ppm}}$ & ${ }^{1} \mathrm{H}_{\delta \mathrm{ppm}}$ \\
\hline 1 & $39.4\left(\mathrm{CH}_{2}\right)$ & $1.05,1.68$ & $39.4\left(\mathrm{CH}_{2}\right)$ & $1.08,1.74$ & $39.5\left(\mathrm{CH}_{2}\right)$ & $1.08,1.72$ \\
\hline 2 & $19.3\left(\mathrm{CH}_{2}\right)$ & $1.50,1.60$ & $19.4\left(\mathrm{CH}_{2}\right)$ & $1.48,1.69$ & $19.5\left(\mathrm{CH}_{2}\right)$ & $1.50,1.62$ \\
\hline 3 & $42.0\left(\mathrm{CH}_{2}\right)$ & $1.19,1.41$ & $42.1\left(\mathrm{CH}_{2}\right)$ & $1.18,1.42$ & $42.2\left(\mathrm{CH}_{2}\right)$ & $1.18,1.42$ \\
\hline 4 & $33.7(\mathrm{C})$ & - & $34.0(\mathrm{C})$ & - & 34.4 (C) & - \\
\hline 5 & $55.4(\mathrm{CH})$ & 1.12 & $55.5(\mathrm{CH})$ & 1.14 & $55.5(\mathrm{CH})$ & 1.13 \\
\hline 6 & $24.2\left(\mathrm{CH}_{2}\right)$ & $1.34,1.74$ & $24.2\left(\mathrm{CH}_{2}\right)$ & $1.35,1.75$ & $24.5\left(\mathrm{CH}_{2}\right)$ & $1.34,1.73$ \\
\hline 7 & $37.9\left(\mathrm{CH}_{2}\right)$ & $2.01,2.40$ & $38.0\left(\mathrm{CH}_{2}\right)$ & $2.01,2.41$ & $38.0\left(\mathrm{CH}_{2}\right)$ & $2.02,2.42$ \\
\hline 8 & $148.1(\mathrm{C})$ & - & $148.6(\mathrm{C})$ & - & $148.4(\mathrm{C})$ & - \\
\hline 9 & $56.5(\mathrm{CH})$ & 1.89 & $56.7(\mathrm{CH})$ & 1.90 & $56.7(\mathrm{CH})$ & 1.92 \\
\hline 10 & 39.7 (C) & - & $39.8(\mathrm{C})$ & - & $40.0(\mathrm{C})$ & - \\
\hline 11 & $24.7\left(\mathrm{CH}_{2}\right)$ & $2.31,2.49$ & $24.4\left(\mathrm{CH}_{2}\right)$ & $2.42,2.62$ & $24.7\left(\mathrm{CH}_{2}\right)$ & $2.42,2.59$ \\
\hline 12 & $160.0(\mathrm{CH})$ & 6.75 & $159.1(\mathrm{CH})$ & 6.57 & $160.0(\mathrm{CH})$ & 6.70 \\
\hline 13 & $134.9(\mathrm{C})$ & - & 139.7 (C) & - & $136.5(\mathrm{C})$ & - \\
\hline 14 & $39.2\left(\mathrm{CH}_{2}\right)$ & $3.39,3.44$ & $28.0\left(\mathrm{CH}_{2}\right)$ & $2.55,2.56$ & $30.0\left(\mathrm{CH}_{2}\right)$ & $3.34,3.36$ \\
\hline 15 & $197.4(\mathrm{CH})$ & 9.62 & $61.0\left(\mathrm{CH}_{2}\right)$ & $3.66,3.67$ & $174.4(\mathrm{C})$ & - \\
\hline 16 & $193.7(\mathrm{CH})$ & 9.39 & $196.1(\mathrm{CH})$ & 9.33 & $196.1(\mathrm{CH}))$ & 9.36 \\
\hline 17 & $108.0\left(\mathrm{CH}_{2}\right)$ & $4.36,4.84$ & $107.9\left(\mathrm{CH}_{2}\right)$ & $4.38,4.84$ & $108.4\left(\mathrm{CH}_{2}\right)$ & $4.39,4.86$ \\
\hline 18 & $33.7\left(\mathrm{CH}_{3}\right)$ & 0.88 & $33.7\left(\mathrm{CH}_{3}\right)$ & 0.88 & $33.8\left(\mathrm{CH}_{3}\right)$ & 0.90 \\
\hline 19 & $21.8\left(\mathrm{CH}_{3}\right)$ & 0.81 & $21.8\left(\mathrm{CH}_{3}\right)$ & 0.81 & $11.9\left(\mathrm{CH}_{3}\right)$ & 0.81 \\
\hline 20 & $14.5\left(\mathrm{CH}_{3}\right)$ & 0.72 & $14.5\left(\mathrm{CH}_{3}\right)$ & 0.74 & $14.8\left(\mathrm{CH}_{3}\right)$ & 0.73 \\
\hline
\end{tabular}

The antifungal activity of epi-curzerenone and furanodienone against Candida albicans, and 8(17),12E-labdadiene- 
15,16-dial against Candida tropicalis and Candida guilliermondii have been reported (Dolara et al., 2000; Morita et al., 1988). The diterpenes are reported to be selectively cytotoxic. They do not affect the Madison Lung Carcinoma (M109) at $2.6 \mu \mathrm{g} / \mathrm{ml}$ while (3) is cytotoxic $\mathrm{ED}_{50} 40 \mu \mathrm{g} / \mathrm{ml}$ against $\mathrm{KB}$ cells (Morita et al., 1988; Zhou et al., 1997).

Cytotoxicity assays are widely used by the pharmaceutical industry to screen for cytotoxicity when searching for a therapeutic that target rapidly dividing cancer cells, for instance or to screen "hits" from initial high-throughput drug screens for unwanted cytotoxic effects before investing in their development. The sesquiterpenes epi-curzerenone (1) and furanodienone (2) were not cytotoxic at $100 \mu \mathrm{g} / \mathrm{ml}$. The reported selective cytotoxicity of the diterpenes agrees with our observation of $8(17), 12 \mathrm{E}-$ labdadiene-15,16-dial (3) and 15-hydroxy-8(17),12E-labdadiene-16-al (4) at 100 $\mu \mathrm{g} / \mathrm{ml}$ to some of the cells tested. These two diterpenes had moderate effect on Mycobacterium aurum while the sesquiterpenes showed no activity in the antimicrobial tests. The moderate antimicrobial activity thus observed gives an insight to the ethnobotanical usage of the plant as it correlates with the usage against infections and as a wound dressing.

The interesting cytotoxic effects of (3) require further investigation to determine its possible usage as an anti-cancer agent. It had moderate effect on the normal cell line Hs 27 and was especially cytotoxic to Jurkat, SH-SY5Y and L929. The compounds (1) \& (2) could be used as anti-trypanosomal agents since they are free of any unwanted cytotoxic effects and have increased activity over the crude extract. Demonstrated MIC values of $6.9 \mu \mathrm{M}$ for sesquiterpenes (1), (2) and $5.3 \mu \mathrm{M}$ for diterpene (3) against $T$. brucei were higher than suramin activity $(\mathrm{MIC}=10 \mu \mathrm{M})$. This is more interesting as suramin the conventional antitrypanosomal agent is known to be highly nephrotoxic and capable of causing adrenal damage.

Some triterpenoids and sterols are already known to have anti-trypanosomal effects against African trypanosome $T$. brucei and the South American trypanosome T. cruzi with some lysis (Hoet et al., 2007). However, the trypanocidal effects of these sesquiterpenes, diterpenes and the crude extract of wild ginger (Siphonochilus aethiopicus) against African trypanosome T. brucei bloodstream forms have not been previously reported. This anti-parasitic effect could explain its traditional usage as a febrifuge since sleeping sickness and malaria both parasitic in origin are major causes of fevers in sub-Saharan Africa. The first stage of sleeping sickness or the haemolymphatic phase entails bouts of fever, headaches, joint pains and itching.

The fresh rhizome and the pure compounds may therefore be used medicinally against sleeping sickness as the rhizome is already widely used in Benue State of Nigeria. It could also find possible usage against nagana in cattle since the rhizome has a milder flavour than the "hot" gingerol containing ginger (Zingiber officinale) and could therefore be more palatlble.

\section{Acknowledgements}

Igoli N. P acknowledges a research visit to the University of Strathclyde, Glasgow in the course of the work.

\section{References}

1. Brieskorn CH, Noble P (1982). Constituents of the Essential Oil of Myrrh II; Sesquiterpenes and Furanosesquiterpenes. Planta Med. 44: 87-90.

2. Burkill HM (2000). Useful Plants of West Tropical Africa. (2 $2^{\text {nd }}$ edn). vol. 5. Families S - Z. Crown Agents for Overseas Governments, London, pp 320-321.

3. Collins LA, Franzblau SG (1997). Microplate Alamar Blue Assay versus BACTEC 460 System for High Throughput Screening of compounds against Mycobacterium tuberculosis and Mycobacterium avium. Antimicrob. Agents and Chemother. 41: 1004-1009.

4. Dolara P, Corte B, Ghelardini C, Pugliese AM, Cerbal E, Menichetti S, Lo Nostro A (2000). Local Anaesthetic, Antibacterial and Antifungal Properties of Sesquiterpenes from Myrrh. Planta Med. 66: 356-358.

5. Firman K, Kinoshita T, Itai A, Sakawa U (1988). Terpenoids from Curcuma heyneana. Phytochemistry. 27: 3887-3891.

6. Franzblau SG, Witzig RS, McLaughlin JC, Torres P, Madico G, Hernandez A, Degnan M T, Cook M B, Quenzer VK, Ferguson RM, Gilman RH (1998). Rapid, Low Technology MIC Determination with Clinical Mycobacterium tuberculosis Isolates by using the Microplate Alamar blue assay. J. Clin. Microbiol. 36:362-366.

7. Hikino H, Konno C, Agastsuma K, Takemoto T, Horibe I, Tori K, Ueyama M, Takeda K (1975). Part XL VII Configuration, Conformation and Thermal Rearrangement of Furanodienone, Isofuranodienone, Curzerenone, Epicurzerenone and Pyrocurzerenone Sesquiterpenoids of Curcuma zedoaria. J. Chem. Soc. Perkin Trans. 1: 478-484.

8. Hoet S, Pieters L, Muccioli GG, Habib-Jiwan J-L, Opperdoes FR, Quentin-Leclereq J (2007). Antitrypanosomal Activity of Triterpenoids and Sterols from the Leaves of Strychnos spinosa and related compounds. J. Nat. Prod. 70: 13601363.

9. Holzapfel CW, Marais W, Wessels PL, Van Wyk BE (2002). Furanoterpenoids from Siphonochilus aethiopicus. Phytochemistry. 59: 405-407.

10. Igoli JO, Ogaji OG, Tor-Anyiin TA, Igoli NP (2005). Traditional Medicine Practices Amongst the Igede people of Nigeria. Part II. Afr. J. Trad. CAM. 2: 134-152.

11. Itokawa H, Yoshimoto S, Morita H (1988). Diterpenes from the Rhizomes of Alpinia formosana. Phytochemistry. 27: $435-438$. 
12. Kiew KY (1980). Taxonomic Studies in the genus Kaempferia (Zingiberaceae). Notes of the Royal Botanic Garden (Edinburgh) 38: 1-12.

13. Kirk RS (1991). Pearson's Composition and Analysis of Foods, Kirk RS, Sawyer R (eds). (9 $9^{\text {th }}$ edn.) Longman, Essex, 393 pp.

14. Lorimer SD, Weavers RT (1987). Foliage Sesquiterpenes and Diterpenes of Podocarpus spicatus. Phytochemistry. 26: 3207-3215.

15. Morita H, Itokawa H (1988). Constituents and Activity of Alpinia galanga. Planta Med. 54: 117-120.

16. Newman D, Fairfield AS, Bhattacharya B, Grifo F, Grupenhoff JT (1997). The Origins of Prescription drugs. In: Grifo F, Rosenthal F (eds) Biodiversity and Human Health, Island Press, Washington, D.C, pp 131-163.

17. Newman DJ, Cragg GM (2007). Natural Products as Sources of new Drugs over the Last 25 years. J. Nat. Prod. 70: 461-477.

18. O'Brien J, Wilson I, Orton T, Pognan F (2000). Investigation of the Alamar Blue (resazurin) fluorescent dye for the assessment of mammalian cell cytotoxicity. Eur. J. Biochem. 267: 5421-5426.

19. Raz B, Iten M, Grether-Buhler Y, Kaminsky R, Brun R (1997). The Alamar Blue assay to determine drug sensitivity of African trypanosomes ( T.B. rhodesiense and T.B. gambiense) in vitro. Acta. Trop. 68: 139-147.

20. Sy L-K, Brown GD (1997). Labdane Diterpenoids from Alpinia chinensis. J. Nat. Prod. 60: 904-908.

21. Xu H-X, Dong H, Sim K-Y (1996). Labdane Diterpenes from Alpinia zerumbet. Phytochemistry. 42: 149-151.

22. Zhou B-N, Baj NJ, Glass TE, Malone S, Werkhoven MCM, van Troon F, David, Wisse JH, Kingston DGI (1997). Bioactive Labdane Diterpenoids from Renealmia alpinia Collected in the Suriname Rainforest. J. Nat. Prod. 60: 1287-1293. 